\title{
ЗАБЕЗПЕЧЕНІСТЬ БДЖОЛОЗАПИЛЕННЯ ОСНОВНИХ СІЛЬСЬКОГОСПОДАРСЬКИХ ЕНТОМОФІЛЬНИХ КУЛЬТУР В УКРАЇНІ
}

\author{
Лісогурська Діна Володимирівна \\ кандидат сільськогосподарських наук, доцент \\ Поліський національний університет \\ ORCID: 0000-0002-2559-6520 \\ E-mail: lisogurskadina@gmail.com
}

Лісогурська Ольга Вікторівна кандидат сільськогосподарських наук, старший викладач

Поліський національний університет ORCID: 0000-0002-3553-9351

E-mail: lisogurskaya2016@gmail.com

Фурман Світлана Володимирівна кандидат ветеринарних наук, доцент Поліський національний університет ORCID: 0000-0002-1079-5797

E-mail: svitlana.furman@ukr.net

Адамчук Леонора Олександрівна кандидат сільськогосподарських наук, доцент Національний університет біоресурсів і природокористування ORCID: 0000-0001-6748-7616

E-mail:leonora.adamchuk@gmail.com

Досліджена забезпеченість бджолозапилення основних сільськогосподарських ентомофрільних культур в Україні (соняшник, гречка, ріпак) та науково обгрунтована необхідність його використання в аграрному виробниитві. Згідно із завданнями дослідження, розрахована структура посівних площ основних сільськогосподарських ентомофрільних культур в Україні у 1990 та 2020 р., проаналізовано динаміку посівних площ основних сільськогосподарських ентомофрільних культур, чисельності бджолиних сімей в Україні за період з 1990 по 2020 р. та урожайність соняшнику та ріпаку в Україні за останні п'ять років (2017-2020рр.). Розрахована кількість бджолиних сімей, яка припадає на 1 гектар соняшнику, ріпаку та гречки і проаналізована забезпеченість їх бджолозапилення. Для цього були використані дані Державної служби статистики України щодо наявності бджолосімей, посівних площ соняшнику, ріпаку та гречки за останні тридиять років (1990-2020 рр.) без урахування тимчасово окупованої території Автономної Республіки Крим, м. Севастополя та частини тимчасово окупованих територій у Донецькій та Луганській областях. Аналіз забезпеченості бджолозапилення основних сільськогосподарських ентомосрільних культур в Україні показує, що на 1 га гречки припадає 13,5 бджолиних сімей, ріпаку - 3,4, соняшнику - 0,4. Наявним бджолиним сім'ям критично не вистачає нектару з гречки для повноцінного взятку, а для повноцінного запилення соняшнику - не вистачає бджолиних сімей. Хоч у середньому в країні вистачає бджолиних сімей для запилення ріпаку озимого, але оскільки розподіл їх нерівномірний, то у деяких областях їх не вистачає, зокрема, у Волинській, Чернігівській, Одеській, Херсонській, Тернопільській, Львівській, Київській. У цих областях на 1 га цієї культури припадає від 0,9 до 1,8 бджолиних сімей. Найбільш складна ситуація в Україні із запиленням соняшнику, особливо у одинадияти областях (Луганська, Херсонська, Дніпропетровська, Запорізька, Кіровоградська, Одеська, Київська, Миколаївська, Харківська, Чернігівська та Донецька), у яких на 1 га посівів цієї культури припадає від 0,1 до 0,4 бджолині сім'ї. На Полтавщині та Черкащині цей показник на рівні нижньої межі $(0,5)$, у решти регіонів коливається в межах 0,6-22,8. Така ситуація, поряд з іншими чинниками, негативно позначається на урожайності соняшнику та ріпаку в Україні. Застосування керованого бджолозапилення, на відміну від екстенсивного шляху виробниитва, дозволить уникнути нераціонального використання грунту, як одного з найважливіших природних ресурсів держави.Це забезпечить економічне зростання, а також сприятиме реалізації державної екологічної політики України.

Ключові слова: ентомофрільні культури, запилення, ріпак, соняшник, гречка.

DOI: https://doi.org/10.32845/bsnau.Ivst.2021.4.16

Згідно з літературними даними, з 1987 по 2016 р. збільшилась кількість загроз для популяцій медоносної бджоли. Якщо раніше головною причиною загибелі бджолиних сімей був варооз, то наразі їх цілий ряд - зміна клімату, інтенсифікація сільського господарства, знищення місць існування, інвазійні види та ін. Це призводить до більш стрімкого зменшення чисельності бджолиних сімей у світі [10].

Зокрема, в Україні з 1992 по 2017 р. кількість колоній популяції бджоли медоносної зменшилася з 3525,7 до 2487,1 тис., тобто у 1,4 раза [15].

Медоносні бджоли та інші запилювачі $€$ важливою умовою збереження біорізноманіття, адже завдяки запиленню збільшується кількість і якість плодів та насіння, підвищується схожість насіння [8]. Зниження їх кількості $€$ серйоз- 
ною проблемою для майбутньої продовольчої безпеки та екологічної стійкості, що має важливі наслідки для управління землекористуванням [16]. Комахи-запилювачі $€$ дуже важливими у цілому для існування екосистем. Ентомофрільними є приблизно 85\% усіх рослин, анемофрільними і аквафільними - 10\%, а самозапильними - лише 5\% [11]. Майже 75\% основних видів сільськогосподарських культур залежить від запилювачів - бджоли медоносної та інших видів диких бджіл[13].

В Україні основними сільськогосподарськими культурами, які залежать від запилення саме бджоли медоносної, $€$ соняшник, ріпак та гречка. Досліджено, що 85,2\% усіх запилювачів соняшника припадає на бджолу медоносну, 7,8 на інших диких бджіл та 7,0\% - на інших комах [14]. Запилення бджолами підвищує врожайність ріпаку та соняшнику. Це відбувається за рахунок збільшення кількості насіння та його маси $[6,7,12]$. Однак підвищення продуктивності відбувається лише тоді, коли дотримані науково обґрунтовані нормативи кількості бджолиних сімей на 1 га посівів цих культур [6].

Вчені, які, за даними ФАО, проаналізували посівні площі та урожайність 87 найважливіших сільськогосподарських культур світу в 1961-2006 р. прийшли до висновку, що дефріцит запилювачів підвищить попит на сільськогосподарські землі. Особливо це буде відчутно у країнах, які розвиваються. Цей зростаючий тиск на пропозицію сільськогосподарської землі може суттєво вплинути на погіршення глобальних екологічних змін. За їхніми прогнозами, відсутність запилення призведе до скорочення сільськогосподарського виробництва на 3-8\% [9]. Тому необхідно здійснювати екологічну інтенсифікацію систем землеробства з метою відновлення чисельності бджоли медоносної та диких запилювачів [10]. Також необхідно розробляти такі технології підвищення продуктивності у рослинництві, які б сприяли збереженню запилювачів [16].

Через зменшення чисельності бджолиних сімей потреба у керованому запиленні у світі стоїть гостро, особливо у США та ЄС, де переважає монокультура. У США, де історія використання бджолозапилення розпочалася ще у 1909

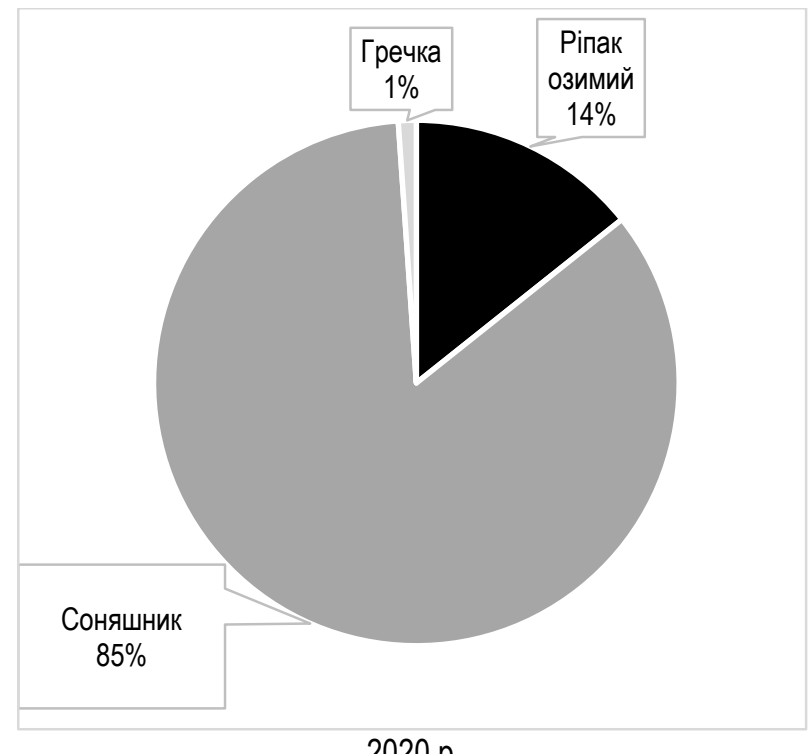

2020 p.

Рис. 1. Структура посівних площ

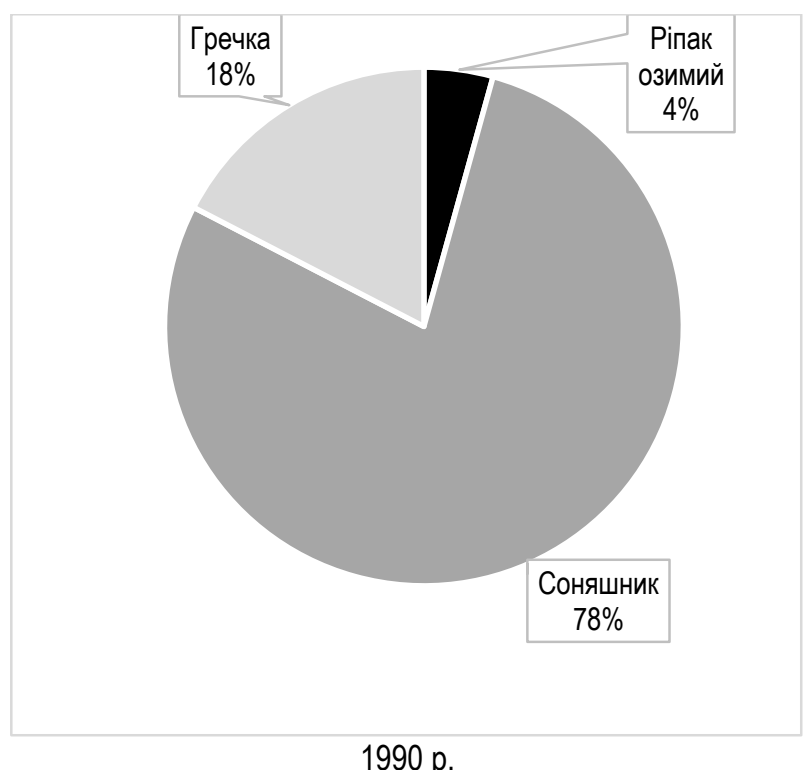

1990 p.

р., визнають його переваги і широко використовують [17]. Надання та отримання таких послуг в Україні бажає бути кращим [1]. Такий стан справ обумовлений двома причинами. Перша - це некомпетентність аграріїв щодо ролі бджолозапилення у формуванні врожайності сільськогосподарських культур. Друга - відсутність таких наукових досліджень, проведених в Україні, які могли б стати вагомим аргументом для фермерів. Тому ми поставили перед собою мету дослідити забезпеченість бджолозапилення основних сільськогосподарських ентомофрільних культур в Україні та науково обґрунтувати необхідність його використання.

Матеріали та методи досліджень. Згідно із завданнями дослідження, була розрахована структура посівних площ основних сільськогосподарських ентомофрільних культур в Україні у період з 1990 та 2020 р., проаналізовано динаміку посівних площ основних сільськогосподарських ентомофільних культур, чисельності бджолиних сімей в Україні з 1990 по 2020 р. та урожайність соняшнику та ріпаку в Україні за останні п'ять років (2017-2020рр.), розрахована кількість бджолиних сімей, яка припадає на 1 на соняшнику, ріпаку та гречки і проаналізована забезпеченість їх бджолозапилення. Для цього були використані дані Державної служби статистики України [5] щодо наявності бджолосімей, посівних площ соняшнику, ріпаку та гречки (основні сільськогосподарські ентомофільні культури) за останні тридцять років (19902020 рр.). без урахування тимчасово окупованої території Автономної Республіки Крим, м. Севастополя та частини тимчасово окупованих територій у Донецькій та Луганській областях.

Результати досліджень. Встановлено, що за останні тридцять років в Україні значно змінилась структура посівних площ, зокрема, основних сільськогосподарських ентомофрільних культур (рис. 1). Наразі соняшник у структурі основних ентомофрільних культур становить $85,5 \%$, ріпак 42,7, гречка - 1,7\%. Гречки в Україні сіють у 78 разів менше, ніж соняшнику та у 13 - ніж ріпаку. Тридцять років назад різниця між гречкою і соняшником становила 4,5 разів, а ріпаку сіяли у 4 рази менше, ніж гречки.

основних сільськогосподарських ентомофільних культур в Україні 
За цей час посіви ріпаку зросли у 12 разів, а соняшнику - в 4 (рис. 2). Натомість посіви гречки зменшились у 4 рази. За десять років (1990 -2000 р). посіви соняшнику зросли у 2 рази, наступні десять років - у 3, а через тридцять років - у 4. Ще стрімкіший ріст відбувався посівів ріпаку. За перші десять років, які досліджувались, площа цієї культури зросла теж у 2 рази, а наступні десять років - у 10 разів і наразі різниця становить 12 разів.

Динаміка чисельності бджолиних сімей в Україні за останні тридцять років прямо протилежна. 31992 по 2000 р. кількість бджолиних сімей зменшилась у 1,2 рази (рис. 3). У наступному десятилітті спостерігалось незначне збільшення сімей, зокрема на 294 тис. Але їх кількість не досягла попереднього рівня. Починаючи з 2010 р., знову відбувся спад і до 2020 р. чисельність бджолиних сімей вже була у 1,3 рази меншою, ніж у 1992 р. Протягом останніх трьох років кількість бджолиних сімей в Україні залишається майже стабільною - більше 2,6 млн.

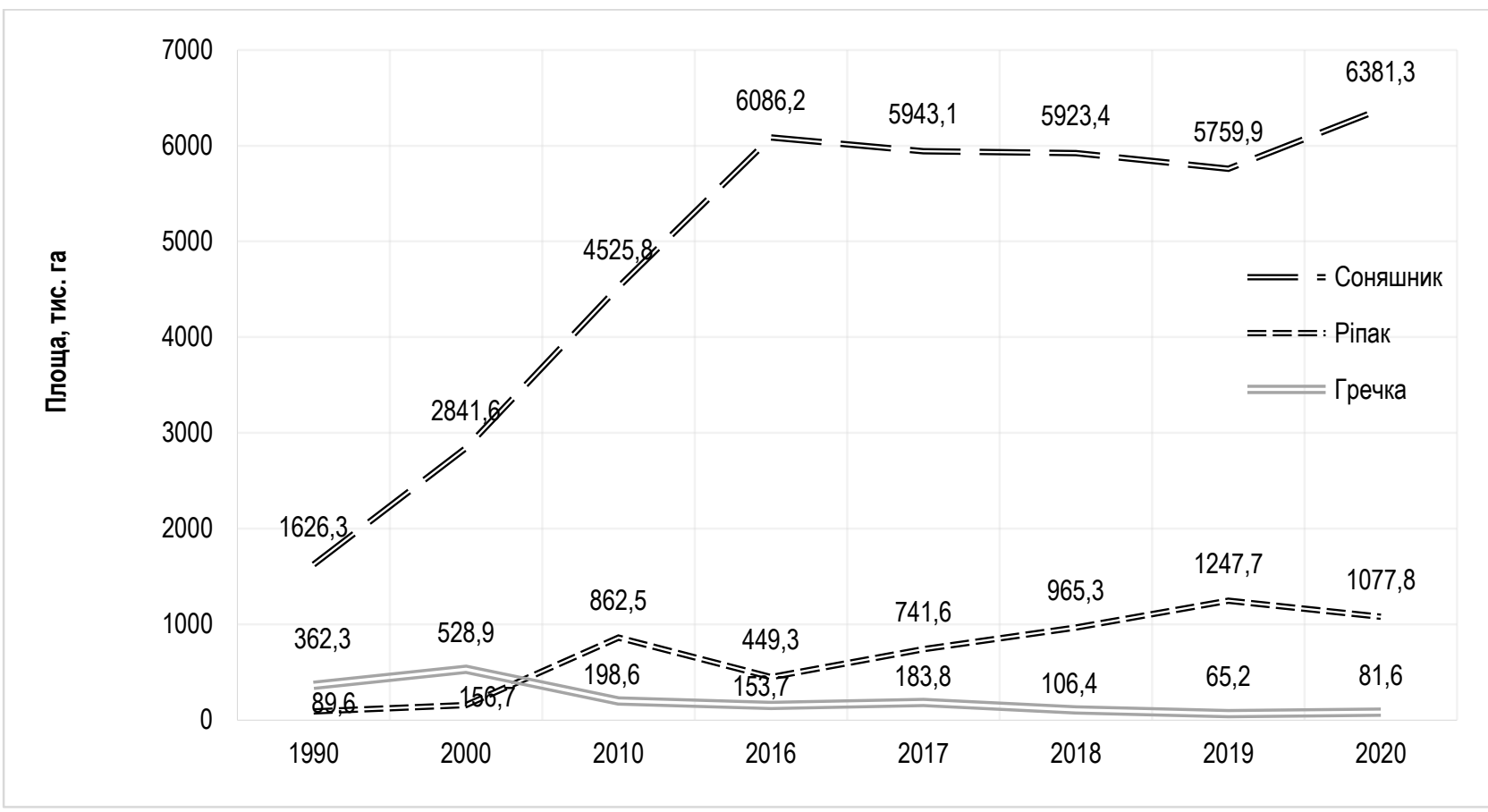

Рис. 2. Динаміка посівних площ

основних сільськогосподарських ентомофільних культурв Україні

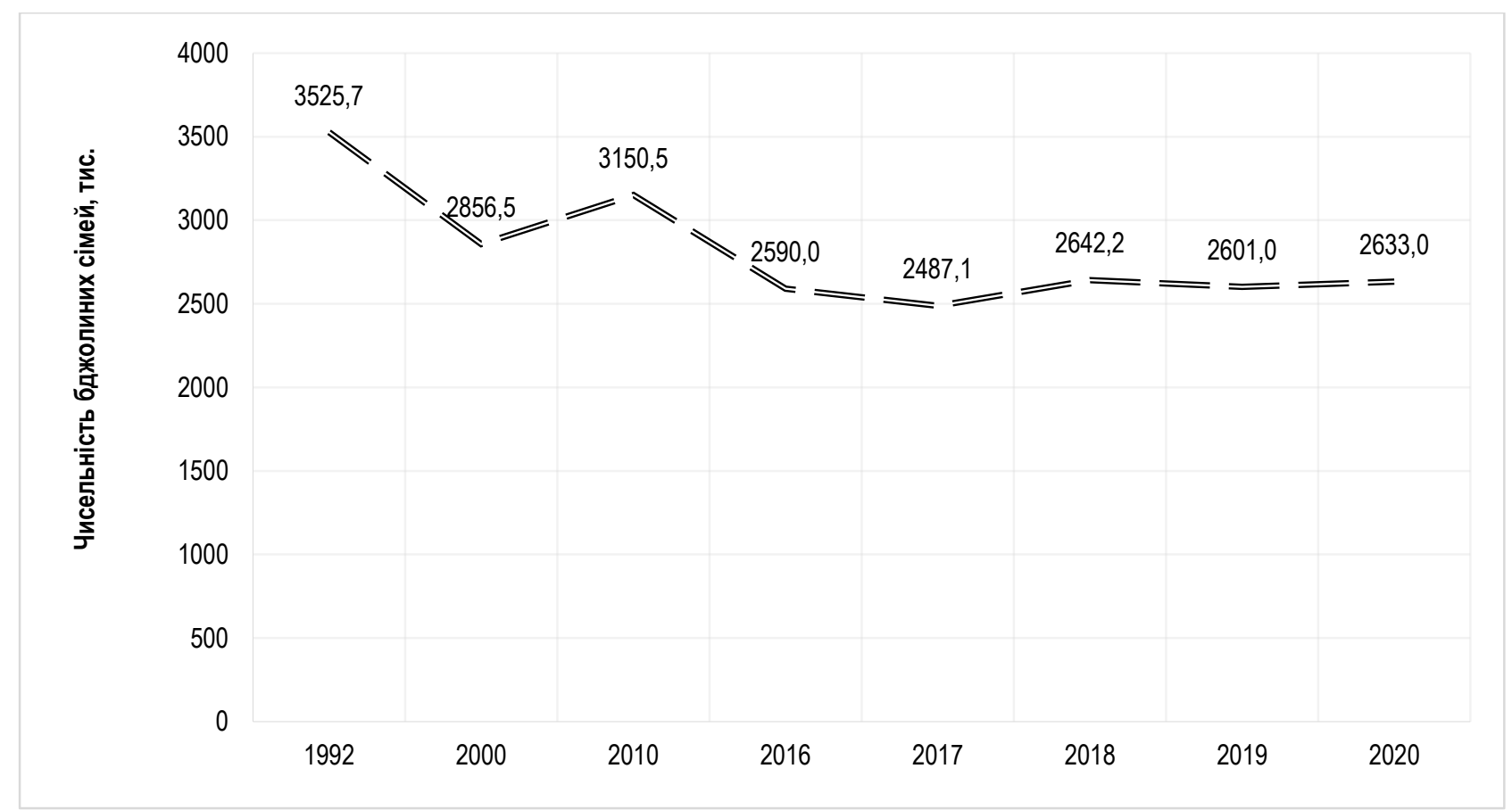

Рис. 3. Динаміка чисельності бджолиних сімей в Україні

Аналіз забезпеченості бджолозапилення основних сільськогосподарських ентомофрільних культур в Україні показує, що на 1 га гречки припадає 13,5 бджолиних сімей, ріпаку - 3,4, соняшнику - 0,4 (табл. 1).

Вісник Сумського національного аграрного університету 
Згідно з літературними даними [4], для повноцінного взятку і запилення ці показники повинні становити для гречки 2,5, для ріпаку - 2, для соняшнику - 0,5-1. Це свідчить про те, що наявним бджолиним сім'ям критично не вистачає нектару з гречки для повноцінного взятку, а для повноцінного запилення соняшнику - не вистачає бджолиних сімей. Кількість бджолиних сімей на 1 га посівів гречки залежно від регіону коливається в межах 3,2-171,3. Хоча у середньому в Україні вистачає бджолиних сімей для запилення ріпаку озимого, але оскільки розподіл їх нерівномірний, то у деяких областях їх не вистачає, зокрема, у Волинській, Чернігівсь- кій, Одеській, Херсонській, Тернопільській, Львівській, Київській. Тут на 1 га цієї культури припадає від 0,9 до 1,8 бджолиних сімей. Найбільш критична ситуація в Україні із запиленням соняшнику, особливо у одинадцяти областях (Луганська, Херсонська, Дніпропетровська, Запорізька, Кіровоградська, Одеська, Київська, Миколаївська, Харківська, Чернігівська та Донецька), у яких на 1 га посівів цієї культури припадає від 0,1 до 0,4 бджолині сім'ї. На Полтавщині та Черкащині цей показник на рівні нижньої межі $(0,5)$, у решти регіонів коливається в межах 0,6-22,8.

Забезпеченість бджолозапилення

Таблиця 1 основних сільськогосподарських ентомофільних культур в Україні, бджолиних сімей/га

\begin{tabular}{|l|c|c|c|}
\hline \multirow{2}{*}{ Pегіон } & \multicolumn{3}{|c|}{ Ентомофільна культура } \\
\cline { 2 - 4 } & гречка & ріпак & соняшник \\
\hline Вінницька & 15,6 & 3,2 & 0,7 \\
\hline Волинська & 7,1 & 0,9 & 1,5 \\
\hline Дніпропетровська & 33,7 & 2,5 & 0,2 \\
\hline Донецька & 23,8 & 10,9 & 0,4 \\
\hline Житомирська & 10,1 & 9,8 & 2,0 \\
\hline Закарпатська & 171,3 & 85,6 & 22,8 \\
\hline Запорізька & 87,3 & 4,6 & 0,2 \\
\hline Івано-Франківська & 46,5 & 5,5 & 4,5 \\
\hline Київська & 4,0 & 1,8 & 0,3 \\
\hline Кіровоградська & 27,8 & 3,3 & 0,2 \\
\hline Луганська & 27,3 & 9,1 & 0,1 \\
\hline Львівська & 7,2 & 1,3 & 1,9 \\
\hline Миколаївська & 44,1 & 5,7 & 0,3 \\
\hline Одеська & 79,4 & 0,9 & 0,2 \\
\hline Полтавська & 22,1 & 16 & 0,5 \\
\hline Рівненська & 10,5 & 2,6 & 1,9 \\
\hline Сумська & 5,5 & 9,6 & 0,6 \\
\hline Тернопільська & 5,1 & 1,2 & 0,7 \\
\hline Харківська & 6,0 & 6,9 & 0,3 \\
\hline Херсонська & 56,6 & 0,9 & 0,1 \\
\hline Хмельницька & 10,0 & 3,5 & 1,2 \\
\hline Черкаська & 29,0 & 3,9 & 0,5 \\
\hline Чернівецька & 70,2 & 8,9 & 4,9 \\
\hline Чернігівська & 3,2 & 1,8 & 0,3 \\
\hline Україна & 13,5 & 3,4 & 0,4 \\
\hline
\end{tabular}

На нашу думку, така ситуація, поряд з іншими чинниками, негативно позначається на урожайності соняшнику та ріпаку в Україні.Нами помічена така тенденція, що високі врожаї цих культур отримують аграрії тих областей, у яких вони повноцінно забезпеченні бджолиними сім'ями для за- пилення. Серед аутсайдерів ті регіони, у яких їх критично не вистачає. В Україні, згідно з даними Держстату, середня урожайність соняшнику за останні п'ять років становила 22,5 ц/га, ріпаку - 26,2, при максимально можливій 33 та 33,3 відповідно (табл. 2).

Таблиця 2

Урожайність соняшнику та ріпаку в Україні, ц/га

\begin{tabular}{|c|c|c|c|c|}
\hline \multirow{2}{*}{ Рік } & \multicolumn{2}{|c|}{ Соняшник } & \multicolumn{2}{c|}{ Ріпак } \\
\cline { 2 - 5 } & середня & максимальна & середня & 32,0 \\
\hline 2016 & 22,9 & 32,1 & 26,2 & 36,4 \\
\hline 2017 & 20,7 & 31,0 & 28,5 & 32,6 \\
\hline 2018 & 23,4 & 32,1 & 27,0 & 32,8 \\
\hline 2019 & 25,9 & 37,6 & 25,9 & 32,7 \\
\hline 2020 & 19,8 & 32,4 & 23,5 & 33,3 \\
\hline
\end{tabular}

Разом з тим наша країна у числі світових лідерівекспортерів олійних культур, тому що збільшує площі посівів цих культур для того, щоб забезпечити високий рівень їх виробництва. Це призводить до порушення сівозміни і, як наслідок, виснаження ґрунтів та зниження їх родючості. За такого екстенсивного шляху, на думку фрахівців[3], не можна надалі розраховувати на підвищення урожайності, адже родючість ґрунту щороку вичерпується. Цього можна досягти лише при застосуванні наукового обґрунтованих сучасних технологій вирощування. Оскільки у деяких областях України максимальна урожайність соняшнику становить не менше $31 \mathrm{kг/га,} \mathrm{а} \mathrm{ріпаку} \mathrm{-} \mathrm{32,} \mathrm{то} \mathrm{резерви} \mathrm{для} \mathrm{її} \mathrm{збільшення} \mathrm{є.} \mathrm{I}$ 
одним із агротехнічних прийомів, який може це забезпечити - бджолозапилення.

Застосування керованого бджолозапилення, на відміну від екстенсивного шляху виробництва, дозволить уникнути нераціонального використання ґрунту як одного з найважливіших природних ресурсів України. Це забезпечить економічне зростання, а також сприятиме реалізації Закону України «Про Основні засади (стратегія) державної екологічної політики України на період до 2030 року» [2].

Висновки. Встановлено, що за останні тридцять років в Україні площі посіву гречки зменшились у 4 рази, а ріпаку і соняшнику зросли у 12 та 4 рази відповідно. Чисельність бджолиних сімей за цей час зменшилася в 1,4 рази. Аналіз забезпеченості бджолозапилення показує, що на 1 га гречки припадає 13,5 бджолиних сімей, ріпаку - 3,4, соняшнику 0,4.Наявним бджолиним сім'ям критично не вистачає нектару 3 гречки для повноцінного взятку, а для повноцінного запилення соняшнику - не вистачає бджолиних сімей. У середньому в країні достатньо бджолиних сімей для запилення ріпаку озимого, але оскільки розподіл їх нерівномірний, то у деяких областях (Волинській, Чернігівській, Одеській, Херсонській, Тернопільській, Львівській, Київській) їх не вистачає (0,9-1,8 на 1 га). Найбільш критична ситуація в Україні із запиленням соняшнику, особливо у одинадцяти областях (Луганська, Херсонська, Дніпропетровська, Запорізька, Кіровоградська, Одеська, Київська, Миколаївська, Харківська, Чернігівська та Донецька), у яких на 1 га посівів цієї культури припадає від 0,1 до 0,4 бджолині сім'ї. Недостатня забезпеченість бджолозапилення ріпаку та соняшнику в Україні може бути однією з причин низької урожайності цих культур. Тому застосування керованого бджолозапилення, на відміну від екстенсивного шляху виробництва, дозволить уникнути нераціонального використання ґрунту як одного 3 найважливіших природних ресурсів нашої країни. Це сприятиме реалізації державної екологічної політики та забезпечить економічне зростання.

\section{Список використаної літератури:}

1. Адамчук Л. О. Ефективне використання бджіл для запилення садів та ягідників : метод. реком. К.: СТ-Друк, 2020. $130 \mathrm{c}$.

2. Закон України «Про Основні засади (стратегія) державної екологічної політики України на період до 2030 року». Верховна рада України : веб-сайт. URL: https://zakon.rada.gov.ua/laws/show/2697-19\#Техt (дата звернення: 20.11.2020).

3. Коваленко Н. П. Екологічно збалансовані сівозміни в системі альтернативного землеробства: історичні аспекти. Агроекологічний журнал. 2012. № 4, С. 95-99.

4. Поліщук В. П. Бджільництво. Лв.: Ред. журналу «Укр. пасічник», 2001. С. 184-186.

5. Сільське господарство. Державна служба статистики: веб-сайт. URL: http://www.ukrstat.gov.ua/operativ/menu/menu_u/cg.htm (дата звернення: 20.11.2021).

6. Abbasi, K. H., Jamal, M., Ahmad, S., Ghramh, H. A., Khanum, S., Khan, K. A., Ullah, M. A., Aljedani, D. M., Zulfiqar B. Standardization of managed honey bee (Apis mellifera) hives for pollination of Sunflower (Helianthus annuus) crop.Journal of King Saud University - Science. 2021. V. 33 (8), P. 1-5. DOI: 10.1016/j.jksus.2021.101608.

7. Aebi A., Vaissiere B. E., Van Engelsdorp D., Delaplane K. S., Roubik D. W., Neumann P. Back to the future: Apis versus non-Apis pollination. Trends in Ecology and Evolution. 2012. V. 27 (3), P. 142-143.

8. Ahmad S., Khalofah A., Khan S.A., Khan K.A., Jilani M.J., Hussain T., Skalicky M, Ghramh H. A, Ahmad Z. Effects of native pollinator communities on the physiological and chemical parameters of loquat tree (Eriobotrya japonica) under open field condition. Saudi J. Biol. Sci. 2021. V. 28 (6), P. 3235-3241. DOI: 10.1016/j.sjbs.2021.02.062.

9. Aizen M. A., Garibaldi L. A., Cunningham S. A., Klein A. M. How much does agriculture depend on pollinators? Lessons from long-term trends in crop production. Ann. Bot. 2009. V. 103 (9), P. 1579-1588. DOI: 10.1093/aob/mcp076.

10. Decourtye A., Cedric A., Le Conte Y., Henry M. Toward the protection of bees and pollination under global change: present and future perspectives in a challenging applied science. Current Opinion in Insect Sciencem. 2019. V. 35, P. $123-131$. DOI: 10.1016/j.cois.2019.07.008.

11. Fattorini R., Glover B. J. Molecular Mechanisms of Pollination Biology. Annu. Rev. Plant Biol. 2020. V. 71, P. 487515. DOI: 10.1146/annurev-arplant-081519-040003.

12. Fuzaro L., Xavier N. L., Carvalho F. J., Nery F. A. N., Carvalho S M., Andalo V. Influence of pollination on canola seed production in the Cerrado of Uberlandia, Minas Gerais State, Brazil. Acta Scientiarum. Agronomy. 2018. V. 40 (1), e39315. DOI: 10.4025/actasciagron.v40i1.39315.

13. Garibaldi L. A., Steffan-Dewenter I., Winfree R., Aizen M. A., Bommarco R., Cunningham S.A. et al. Wild pollinators enhance fruit set of crops regardless of honey bee abundance. Science. 2013. V.339 (6127), P. 1608-1611. DOI: $10.1126 /$ science.1230200.

14. Lajos K., Samu F., Bihaly A. D., Fülöp D., Sárospataki M. Landscape structure affects the sunflower visiting frequency of insect pollinators. Sci. Rep. 2021. 11 (1), P. 1-11. DOI: 10.1038/s41598-021-87650-9.

15. Lisohurska O. V., Lisohurska D. V., Sokolyuk V. M., Furman S. V., Kryvyi M. M., Ligomina I. P. Inventory of managed honey bee population in Zhytomyr region (Ukraine). Ukrainian Journal of Ecology. 2020. V. 10 (1), P. $133-137$. DOI: 10.15421/2020_21.

16. Maderson S., Wynne-Jonesa S. Beekeepers' knowledges and participation in pollinator conservation policy. Journal of Rural Studies. 2016. V. 45, P. 88-98. DOI: 10.1016/j.jurstud.2016.02.015.

17. Morse R. A., Calderone N.W. The value of honey bees as pollinators of U.S. crops in 2000. Bee Culture. 2000. V. 132 (3), P. 1-15.

References:

1. Adamchuk, L. A., 2020. Efektyvne vykorystannja bdzhil dlja zapylennja sadiv ta jaghidnykiv: metod. rekom. [Effective use 
of bees for pollination of orchards and berries : guidelines]. Kyiv: ST-Druk.

2. Law of Ukraine "On the Basic Principles (Strategy) of the State Environmental Policy of Ukraine for the period up to 2030». Verkhovna Rada of Ukraine. Available at: <https://zakon.rada.gov.ua/laws/show/2697-19\#Text> [Accessed 20 November 20211.

3. Kovalenko. N. P., 2001. Ekologhichno zbalansovani sivozminy v systemi aljternatyvnogho zemlerobstva: istorychni aspekty [Ecologically balanced crop rotations in the system of alternative agriculture: historical aspects]. Aghroekologhichnyj zhurnal, no. 4, pp. 95-99.

4. Polishhuk, V. P., 2001. Bdzhiljnyctvo [Beekeeping]. Lviv: Red. zhurnalu «Ukr. pasichnyk».

5. Agriculture. State Statistics Service. Available at: $<$ http://www.ukrstat.gov.ua/operativ/menu/menu_u/cg.htm $>[A c c e s s e d$ 20 November 2021].

6. Abbasi, K. H., Jamal, M., Ahmad, S., Ghramh, H. A., Khanum, S., Khan, K. A., Ullah, M. A., Aljedani, D. M., Zulfiqar, B., 2021. Standardization of managed honey bee (Apis mellifera) hives for pollination of Sunflower (Helianthus annuus) crop. Journal of King Saud University - Science, no. 33 (8), pp. 1-5. doi: 10.1016/j.jksus.2021.101608.

7. Aebi, A., Vaissiere, B. E., Van Engelsdorp, D., Delaplane, K. S., Roubik, D. W., Neumann, P., 2012. Back to the future: Apis versus non-Apis pollination. Trends in Ecology and Evolution, no. 27 (3), pp. 142-143.

8. Ahmad, S., Khalofah, A., Khan, S.A., Khan, K.A., Jilani, M.J., Hussain, T., Skalicky, M, Ghramh, H. A, Ahmad, Z., 2021. Effects of native pollinator communities on the physiological and chemical parameters of loquat tree (Eriobotrya japonica) under open field condition. Saudi J. Biol. Sci, no. 28 (6), pp. 3235-3241. doi: 10.1016/j.sjbs.2021.02.062.

9. Aizen, M. A., Garibaldi, L. A., Cunningham, S. A., Klein, A. M., 2009. How much does agriculture depend on pollinators? Lessons from long-term trends in crop production. Ann. Bot., no. 103 (9), pp. 1579-1588. doi:10.1093/aob/mcp076.

10. Decourtye, A., Cedric, A., Le Conte, Y., Henry, M., 2019. Toward the protection of bees and pollination under global change: present and future perspectives in a challenging applied science. Current Opinion in Insect Sciencem, no. 35, pp. 123-131. doi: 10.1016/j.cois.2019.07.008.

11. Fattorini, R., Glover, B. J., 2020. Molecular Mechanisms of Pollination Biology. Annu. Rev. Plant Biol., no. 71, pp. 487-515. doi: 10.1146/annurev-arplant-081519-040003.

12. Fuzaro, L., Xavier, N. L., Carvalho, F. J., Nery, F. A. N., Carvalho, S M., Andalo, V., 2018. Influence of pollination on canola seed production in the Cerrado of Uberlandia, Minas Gerais State, Brazil. Acta Scientiarum. Agronomy., no. 40 (1), e39315. doi: 10.4025/actasciagron.v40i1.39315.

13. Garibaldi, L. A., Steffan-Dewenter, I., Winfree, R., Aizen, M. A., Bommarco, R., Cunningham, S.A. et al., 2013. Wild pollinators enhance fruit set of crops regardless of honey bee abundance. Science, no.339 (6127), pp. 1608-1611. doi: 10.1126/science.1230200.

14. Lajos, K., Samu, F., Bihaly, A. D., Fülöp, D., Sárospataki, M., 2021. Landscape structure affects the sunflower visiting frequency of insect pollinators. Sci. Rep., no. 11 (1), pp. 1-11. doi: 10.1038/s41598-021-87650-9.

15. Lisohurska, O. V., Lisohurska, D. V., Sokolyuk, V. M., Furman, S. V., Kryvyi, M. M., Ligomina, I. P., 2020. Inventory of managed honey bee population in Zhytomyr region (Ukraine). Ukrainian Journal of Ecology, no. 10 (1), pp. 133-137. doi: 10.15421/2020_21.

16. Maderson, S., Wynne-Jonesa, S., 2016. Beekeepers' knowledges and participation in pollinator conservation policy. Journal of Rural Studies, no. 45, pp. 88-98. doi: 10.1016/i.jurstud.2016.02.015.

17. Morse, R. A., Calderone, N. W., 2000. The value of honey bees as pollinators of U.S. crops in 2000. Bee Culture, no. 132 (3), pp. 1-15.

Lisohurska Olga Viktorivna, Candidate of Agricultural Sciences, Senior Lecturer

Lisohurska Dina Volodymyrivna, Candidate of Agricultural Sciences, Associate Professor

Furman Svitlana Volodymyrivna, Candidate of Veterinary Sciences, Associate Professor

Polissia National University (Zhytomyr, Ukraine)

Adamchuk Leonora Alexandrovna, Candidate of Agricultural Sciences, Associate Professor

National University of Life and Environmental Sciences (Kyiv, Ukraine)

Provision of bee pollination of the main agricultural entomophilic crops in Ukraine

The provision of bee pollination of the main entomophilous crops in Ukraine (sunflower, buckwheat, rape) has been studied and the necessity of its use in agricultural production has been scientifically substantiated. According to the objectives of the study, the structure of sown areas of major agricultural entomophilic crops in Ukraine in 1990 and 2020 was calculated, the dynamics of sown areas of major agricultural entomophilic crops, the number of bee families in Ukraine for the period from 1990 to 2020 and the yield of sunflower and rapeseed in Ukraine for the last five years (2017-2020). The number of bee colonies per 1 hectare of sunflower, rapeseed and buckwheat was calculated and the security of their bee pollination was analyzed. For this purpose, data from the State Statistics Service of Ukraine on the presence of bee colonies, sown areas of sunflower, rape and buckwheat for the last thirty years (1990-2020) were used, excluding the temporarily occupied territory of the Autonomous Republic of Crimea, Sevastopol and part of the temporarily occupied territories in Donetsk. and Luhansk regions. Analysis of bee pollination of the main entomophilous crops in Ukraine shows that there are 13.5 bee colonies per 1 hectare of buckwheat, 3.4 rapeseed rape, and 0.4 per hectare of sunflower. Existing bee colonies are critically short of buckwheat nectar for a full bribe, and there are not enough bee colonies for full sunflower pollination. Although on average there are enough bee colonies in the country to pollinate winter oilseed rape, but because their distribution is uneven, they are lacking in some oblasts, in particular, in Volyn, Chernihiv, Odesa, Kherson, 
Ternopil, Lviv, and Kyiv. In these areas per 1 hectare of this crop there are from 0.9 to 1.8 bee colonies. The most difficult situation in Ukraine with sunflower pollination, especially in eleven regions (Luhansk, Kherson, Dnipropetrovsk, Zaporizhia, Kirovohrad, Odessa, Kyiv, Mykolaiv, Kharkiv, Chernihiv and Donetsk), where 1 hectare of crops of this crop has from 0.1 up to 0.4 bee families. In Poltava and Cherkasy regions this indicator is at the level of the lower limit (0.5), in other regions it ranges from 0.6 to 22.8. This situation, along with other factors, negatively affects the yield of sunflower and rapeseed in Ukraine. The use of controlled bee pollination, in contrast to the extensive way of production, will avoid irrational use of soil as one of the most important natural resources of the state. This will ensure economic growth and promote the implementation of state environmental policy of Ukraine.

Key words: entomophilic crops, pollination, rapeseed, sunflower, buckwheat.

Дата надходження до редакції: 29.11.2021 р. 